\title{
Comparative historical analysis of four UK hotel companies, $1979-2004$
}

\author{
Dr. Mary Quek
}

University of Hertfordshire

E-mail: m.j.quek@herts.ac.uk

Tel: + $44(0) 1707285881$

Fax: + 44 (0) 1707285455

$\begin{array}{ll}\text { Submitted } & \text { : June } 302009 \\ \text { 1rst Revision } & \text { : September } 282009 \\ 2^{\text {nd }} \text { Revision } & \text { : November } 12010 \\ \text { Accepted } & :\end{array}$

\section{Abstract}

Purpose - This paper examines why and how M\&A activity has been used by UK hotel companies over a 26 year period and provides a preliminary exploration of its relative success, given that the $M \& A$ literature suggests high failure rates or $M \& A$ transactions which do not achieve their objectives.

Design/methodology/approach - This research is based on a combination of a multiple-case study and comparative historical analysis to bring out the different levels of analysis embedded in past M\&A literature and to identify changes of motives for undertaking M\&A activities based on companies and their external environment.

Findings - Value maximizing motives are prevalent whilst non-value maximizing motives are not supported. The acquisition of brand names and rights is a major motive for the UK hotel industry, particularly, in the light of global competition and the brand power that enables companies to expedite growth while at the same time reducing financial risks.

Practical implications - This longitudinal study serves to reinforce the type of target companies, particularly those that share similar resources or end products, for acquiring companies to select from in order to expect a higher M\&A success rate. 
Originality/value - This paper provides the first empirical study to integrate the comparative historical analysis approach with strategic management M\&A theory to trace and understand how and why UK hotel companies became leading international companies. Through this interdisciplinary approach, the importance of acquiring a brand name is illustrated and identified as an essential motive, specific to the hotel industry.

Key words - Business history, Comparative historical analysis, Hotel industry, Merger and acquisition activity, UK Hotel companies

Paper type - Research

\section{Introduction}

Merger and acquisition (M\&A) activities [1] are commonly used as a form of growth strategy and means for organizations to improve profitability or to survive in an increasingly competitive environment (van Dick et al., 2006). These activities have generated a broad range of management research encompassing disciplines such as finance (Halpern, 1983; Singh and Montgomery, 1987), strategic management (Berkovitch and Narayanan, 1993; Lubatkin, 1983) management behavioral studies (Berkovitch and Narayanan, 1993; Jensen, 1986; Marris, 1964) and operational study (Hakkinen et al., 2004), attempting to evaluate and understand companies' performances. However, research in the past 30 years shows that the use of M\&A as a tool for business expansion has yielded a high failure rate of $44-50 \%$ (Cartwright and Schoenberg, 2006). Yet this method of growth has continued to be widely adopted by business practitioners and the motives behind this remain a puzzle to academia.

A review of the M\&A literature identified that most studies approached the phenomenon from one level, either an organizational level (Jensen and Meckling, 1976; Marris, 1964; Salter and Weinhold, 1979; Schoenberg, 2003; Singh and Montgomery, 1987; Teece, 1980) or an industry level (Andrade et al., 2001; Harford, 2005; Mitchell and Mulherin, 1996). Although a number of researchers (Blair and Schary, 1993; Klasa and Stegemoller, 2007; Mulherin and Boone, 2001) have attempted to understand it through the integration of both levels, the methodology used in 
these studies involved large sample sizes and / or mixtures of industries, leading to inconclusive results as to M\&A performance.

Against this background, this paper aims to fill the gap by examining a combination of a small sample from a single industry - hotel companies - and the integration of motives for M\&A activities at both organizational and industry levels. In addition, the application of a comparative historical analysis approach, which analyzes the interactions between organizational motives and external environmental factors over two decades, revealed a high number of M\&A activities. Yet, studies conducted within the hotel industry, either in relation to the M\&A activities (Table 1) or historical development (Table 2) are found to be few. Table 1 presents a list of research studying hotel development and M\&A activities.

Table 1: Studies of hotel development and M\&A activities

\begin{tabular}{|l|l|l|}
\hline $\begin{array}{l}\text { Period } \\
\text { studied }\end{array}$ & Author(s) & \\
\hline $1945-$ & $\begin{array}{l}\text { Stewart } \\
(1996)\end{array}$ & $\begin{array}{l}\text { The author provides a comprehensive view of the development of 12 hotel } \\
\text { companies in the UK between World War II and the 1980s. Although his study } \\
\text { concentrated on the UK hotel industry and M\&A activities formed part of his } \\
\text { investigation, there is a lack of in-depth evaluation of the companies and } \\
\text { environmental factors. }\end{array}$ \\
\hline 1980 s & $\begin{array}{l}\text { Kwansa } \\
(1994)\end{array}$ & $\begin{array}{l}\text { This article focuses on M\&A performances in terms of shareholders' wealth in } \\
\text { acquired hotel companies in the US. It concludes that shareholders of acquired } \\
\text { hotel companies in the 1980s had benefited from the M\&A activities. However, this } \\
\text { study was limited to an organization perspective. }\end{array}$ \\
\hline 1980 s & $\begin{array}{l}\text { Mahjan et } \\
\text { al. (1994) }\end{array}$ & $\begin{array}{l}\text { This paper aims to propose a methodology to practitioners by exploring how the } \\
\text { perceived importance of brand equity of a potential target company in M\&A activity } \\
\text { can be determined. This study focuses on the US industry and the period examined } \\
\text { concentrates on the 1980s. }\end{array}$ \\
\hline 1980 s & $\begin{array}{l}\text { Arbel and } \\
\text { Woods } \\
(1988)\end{array}$ & $\begin{array}{l}\text { The focus of this paper is to provide a list of anti-takeover strategies as the number } \\
\text { of M\&A activities increased during the 1980s. It was not written to evaluate the } \\
\text { motives for M\&A activities, but to provide a conceptual proposition, particularly } \\
\text { about anti-hostile takeover strategies. Moreover, the geographical focus was based } \\
\text { on the US and the period examined was confined to the 1980s. }\end{array}$ \\
\hline $1981-$ \\
1988
\end{tabular}




\begin{tabular}{|l|l|l|}
\hline & (1990) & environment was limited. \\
\hline $1982-$ & $\begin{array}{l}\text { Canina } \\
\text { (2001) }\end{array}$ & $\begin{array}{l}\text { This article focuses on acquiring and acquired hotel companies, particularly on M\&A } \\
\text { activities and their effects on shareholders' wealth. The author extended Kwansa's } \\
\text { research, in terms of the period of study, from the 1980s to the year 1999. } \\
\text { However, this study is confined to one level of investigation, namely the } \\
\text { organizational perspective. }\end{array}$ \\
\hline 1990s & $\begin{array}{l}\text { Kim and } \\
\text { Olsen }\end{array}$ & $\begin{array}{l}\text { This paper aims to find the critical success factors for value creation in the lodging } \\
\text { industry with the use of corporate M\&A activities. It presents a multi-dimensional } \\
\text { framework, which encompasses the pre-acquisitions management process, post- } \\
\text { acquisition integration process and post-acquisition performance. Although it } \\
\text { provides a list of acquisition objectives derived from the interviews with hoteliers } \\
\text { and industry consultants which concur with the M\&A literature in general, this study } \\
\text { provided a one-sided analysis, via the organizational view, and does not integrate } \\
\text { the external factors which are influential on decision makers and their M\&A } \\
\text { activities. It is based on a cross-sectional study in the 1990s. }\end{array}$ \\
\hline
\end{tabular}

It is apparent that there is an absence of a holistic approach in the studies of the development of hotel companies, in general and the hotel industry and M\&A activities, in particular. Although the historical studies discussed in Table 2 provide a comprehensive narration of the evolution of the UK hotel industry from A.D. 400 to the late 1980s, these studies demonstrate a lack of analysis of UK hotel companies' development and M\&A activities at two levels - organizational and external environmental factors. This research has concentrated on the UK hotel industry because UK is the first industrialized country and was one of the first to develop its service economy (Cassis, 1997; Wardley, 1991). Moreover, the historical attractions and London's position as one of the most important business cities are the drivers for increasing the number of tourist visits and nights spent. This is evident from the amount of income generated by overseas visitors' (business and holiday) in the UK; from £2.8 billion spent in 1979 to £27.8 billion in 2004, and £31.9 billion in 2008 (Office for National Statistics, 2000;2009). Therefore, the UK hotel industry is deemed suitable for investigation in this paper.

Table 2: Historical studies of the UK hotel industry

\begin{tabular}{|l|l|l|}
\hline $\begin{array}{c}\text { Period } \\
\text { studied }\end{array}$ & Author(s) & \\
\hline $\begin{array}{l}\text { From } \\
\text { A.D. } 43 \\
\text { until the }\end{array}$ & $\begin{array}{l}\text { Borer } \\
(1972)\end{array}$ & $\begin{array}{l}\text { Narrates the historical evolution of different types of accommodation from A.D. } 43 \\
\text { to the 1970s. The author makes use of archival data and secondary sources to } \\
\text { provide an account of the development of British accommodation, emphasizing }\end{array}$ \\
\hline
\end{tabular}




\begin{tabular}{|c|c|c|}
\hline 1970s & & $\begin{array}{l}\text { the context of transportation change since the } 13^{\text {th }} \text { century. It highlights the shift } \\
\text { from the use of horses, stage coaches and mail coaches to railways and motor } \\
\text { cars which illuminate the different degrees of hospitality received by travelers. }\end{array}$ \\
\hline $\begin{array}{l}\text { From the } \\
\text { mid } 19^{\text {th }} \\
\text { century to } \\
1974 \text {. }\end{array}$ & $\begin{array}{l}\text { Taylor } \\
\text { and Bush } \\
(1974)\end{array}$ & $\begin{array}{l}\text { Highlight the evolution of the UK hotel industry through the stories of major events } \\
\text { that took place and presents several prominent hoteliers and their contributions } \\
\text { between } 1837 \text { and } 1862 \text {. This book is based on secondary sources such as } \\
\text { books, trade journals and newspapers and examines predominantly the growth of } \\
\text { luxurious British hotels. It also examines the development of railway hotels and } \\
\text { the introduction of lodgings for the poor briefly. The focus on the luxury market } \\
\text { (equivalent to the five-star market in this study) is not surprising since the wealthy } \\
\text { and famous were the main patrons of hotels during the period studied. }\end{array}$ \\
\hline $\begin{array}{l}\text { From } \\
\text { early } \\
\text { times to } \\
1975\end{array}$ & $\begin{array}{l}\text { Medlik } \\
\text { and Airey } \\
\text { (1978) }\end{array}$ & $\begin{array}{l}\text { Provides an overview of the evolution of the hotel and catering industry through a } \\
\text { multi-level discussion comprising the companies, industry and institutions in the } \\
1970 \text { s. It is based on secondary sources; material from government departments, } \\
\text { international organizations and trade journals and offers a brief historical } \\
\text { development and evaluates the characteristics and structures of these industries. }\end{array}$ \\
\hline $\begin{array}{l}1839 \\
1914\end{array}$ & $\begin{array}{l}\text { Simmons } \\
(1984)\end{array}$ & $\begin{array}{l}\text { Examines the development of the UK hotel industry through the development of } \\
\text { railways and their impacts on the growth of hotels and tourism in Great Britain } \\
\text { between } 1839 \text { and } 1914 \text {. This paper is based on both archival documents from } \\
\text { the National Archive and secondary data such as books and trade magazines. It } \\
\text { demonstrates that the extension of railway lines facilitated hotel development in } \\
\text { major cities and rural areas. }\end{array}$ \\
\hline $\begin{array}{ll}\text { From } & \\
1837 \\
1987\end{array}$ to & $\begin{array}{l}\text { Taylor } \\
(2003)\end{array}$ & $\begin{array}{l}\text { This book extends the narration of the development of the hotel industry written by } \\
\text { Taylor and Bush (1978) from the 1970s to the 1980s. Data were retrieved from } \\
\text { secondary sources: books, trade journals and newspapers. This book covers } \\
\text { more events than the earlier book. For instance, two World Wars and more } \\
\text { entrepreneurs and hotel operators contributing to the growth of the UK hotel } \\
\text { industry were added. The two World Wars highlighted the fact that the role of } \\
\text { hotels was not confined to being an economic contributor to the country, but also } \\
\text { had its social contribution as a functional unit for the facilitation of food rationing, } \\
\text { shelters for school children and accommodation for those displaced from their } \\
\text { homes, as well as for both domestic and overseas military groups. }\end{array}$ \\
\hline $\begin{array}{l}\text { From the } \\
\text { early } 20^{\text {th }} \\
\text { Century }\end{array}$ & $\begin{array}{l}\text { Nickson } \\
\text { (1997) }\end{array}$ & $\begin{array}{l}\text { Explores the historical development of the hospitality industry by reviewing the } \\
\text { autobiographies and biographies of four industry entrepreneurs who started four } \\
\text { well-known hospitality companies from the early } 20^{\text {th }} \text { century. It provides a broad } \\
\text { understanding of how the hospitality industry started. The four hotel companies } \\
\text { studied were Forte Group plc (UK), Hilton Hotels Corporation (USA), Marriott } \\
\text { International (USA) and Holiday Inn Hotels (USA). Although this article does not } \\
\text { provide an in-depth discussion of the historical development of the hotel industry, } \\
\text { it contributes to the provision of an agenda for further research in the area of } \\
\text { historical analysis, specifically on the hotel industry. }\end{array}$ \\
\hline $\begin{array}{l}1924 \\
1938\end{array}$ & $\begin{array}{l}\text { Pope } \\
(2001)\end{array}$ & $\begin{array}{l}\text { Examines the development of hotel companies by studying the consumer services } \\
\text { provided between the period } 1924 \text { to } 1938 \text {. The author used financial documents } \\
\text { of companies retrieved from the National Archives in the most part, and to a } \\
\text { smaller extent, trade journals and books, to examine the financial performance of } \\
\text { three hotel companies. These companies were positioned in three different } \\
\text { market levels in this industry: the Savoy (five-star); the London, Midland and } \\
\text { Scottish Railway (three-star) and Trust Houses (two-star). Although this study } \\
\text { mentions that M\&A activity was used by Trust Houses as a major tool for }\end{array}$ \\
\hline
\end{tabular}




\begin{tabular}{|c|c|c|}
\hline & & $\begin{array}{l}\text { expansion, the author does not provide a more in-depth investigation of the } \\
\text { method used. }\end{array}$ \\
\hline $\begin{array}{l}1918 \\
1939\end{array}$ & $\begin{array}{l}\text { Pope } \\
(2000)\end{array}$ & $\begin{array}{l}\text { This article studies the development of railway resort hotels in Great Britain from } \\
1918 \text { to } 1939 \text { by using a combination of archival data retrieved from the National } \\
\text { Archives and secondary data obtained from articles, trade journals and } \\
\text { government organizations. Particular emphasis was placed on the management } \\
\text { responses to external demand change to explain railway hotel development } \\
\text { before the Second World War. }\end{array}$ \\
\hline $\begin{array}{l}1930 s \\
1980 s\end{array}$ & $\begin{array}{l}\text { Stewart } \\
(1991)\end{array}$ & $\begin{array}{l}\text { Narrates the growth and development of Trust Houses and Forte Holdings by } \\
\text { tracing their past. This article provides a comprehensive background of the early } \\
\text { development of Forte Group plc by describing how Charles Forte founded his } \\
\text { business. The author also briefly evaluates the success of Forte Group plc. One } \\
\text { of the success factors for Forte Group plc was based on the experience } \\
\text { accumulated in M\&A activities via a range of professional advice received after the } \\
\text { company's resistance of the Allied Breweries bid in 1971. The other may be } \\
\text { ascribed to Charles Forte, who was considered to possess a unique } \\
\text { entrepreneurial style in business. This article was an early part of a larger piece of } \\
\text { work in Stewart's (1996) PhD thesis. }\end{array}$ \\
\hline $\begin{array}{l}1945 \\
1989\end{array}$ & $\begin{array}{l}\text { Stewart } \\
(1996)\end{array}$ & $\begin{array}{l}\text { This thesis studies the development of } 12 \text { UK hotel companies between } 1945 \text { and } \\
\text { 1989. Data were collected from company archival documents and interviews with } \\
\text { hoteliers from these companies. M\&A activities were mentioned in these studies, } \\
\text { but there was a lack of in-depth discussion of why and how M\&A activities were } \\
\text { used. Moreover, the period of study ends in } 1987 \text { and several major world and } \\
\text { economic events have occurred since to change the structure of the UK hotel } \\
\text { industry. }\end{array}$ \\
\hline
\end{tabular}

This paper is structured in the following manner: the second section evaluates the M\&A literature; the third section explains the sample and method used to carry out this study; the fourth and fifth sections present the findings and discussions respectively; the sixth section discusses the conclusion; and the seventh section provides the implications for practitioners; finally, this paper concludes by proposing areas for further research.

\section{Merger and acquisition activities (M\&A activities)}

The motives found in M\&A literature are many and existing studies regarding the consequences of M\&A activity are often inconclusive because it is difficult to identify specific motives and this is further complicated by the changes of motivations over time (Kiymaz and Baker, 2008). 
Research studying the organizational level is dominated by value maximization or non-value maximization motives. The general argument about the value-maximizing motive is the creation of expected value through synergies for shareholders of both the acquiring and acquired company (Barkema and Schijven, 2008; Berkovitch and Narayanan, 1993). Value maximizing motives are underlined by assumptions about creating value through M\&A activities and are generally linked to economies of scale and scope, speed and market share (Hopkins, 2008; Salter and Weinhold, 1979; Schoenberg, 2003; Singh and Montgomery, 1987; Teece, 1980).

According to Salter and Weinhold (1979), the underlying forces for realizing economies of scale and scope in the combined companies are to do with the relationship between supplementary and complementary resources. Supplementary resources entail there being similar resources which reduce cost or add value to the existing products in the new entity, while complementary resources refer to the addition of the same kind of resources to reduce cost or add value to the merged company. In a similar vein, Halpern (1983) argued that economies of scale are gained through horizontal M\&A activities when excess capacity in some factor(s) of production, such as people and physical facilities, are eliminated. In addition to the elimination of excess capacity, Barkema and Schijven (2008) and Häkkinen et al. (2004) agreed that costs are reduced through efficient procurement, production, administration and marketing processes.

Likewise, economies of scope can be attained as a company grows, when the same resources are used to produce or distribute a wider range of products (Gaughan, 2007; Singh and Montgomery, 1987). Teece (1980) posited that the sharing of specialized know-how between companies is an important source of scope economies. Singh and Montgomery (1987) argue that scope economies can occur outside the production area, for example in distribution systems, while intangible assets like brand names can be the source of scope economies if they are used for more than one product. From a different angle, Ingram et al. (1992) and Schoenberg (2003: 98) argued that the acquisition of a company that is already operating in the desired product area gives 'immediate access' to an established distribution channel and its valuable shelf space. Speed in M\&A activities could provide the company with an established 
market position if the latter is a late entrant relative to its competitors into a particular product or geographic market (Schoenberg, 2003).

Value maximizing motives are also achieved when a merged company obtains greater market power through increased market share (Barkema and Schijven, 2008; Gaughan, 2007; Singh and Montgomery, 1987). Gaughan (2007) links the source of market power to market share and the monopoly power deriving from the company's ability to set and maintain prices above competitive levels. Other authors argued that market share is increased when the acquiring and the acquired company were operating in the same product market, or the combined companies extended their range of products or markets and increased their effective size relative to competitors (Hitt et al., 1998; Singh and Montgomery, 1987).

In a different way, M\&A activities studied at the organizational level also suggested a non-value maximizing motive. This motive is underpinned by managerial theory, which proposes that managers aim to grow a company bigger so as to obtain greater managerial power and welfare, even at the expense of profitability (Berkovitch and Narayanan, 1993; Jensen and Meckling, 1976; Marris, 1964). Jensen and Meckling's (1976) interpretation of agency theory suggest that corporate managers serve as the agents of shareholders, yet the relationship between shareholders and corporate managers is often conflicting because of the choice between paying out excess cash to shareholders or re-investing in other projects. It is assumed that paying out to shareholders reduces the resources under managers' control, thereby reducing managers' power. Similarly, Jensen (1986) argued that management's intent is to control a larger empire. Although Marris (1964) had noted that such motivation exists, he also suggested that the behavior of managers who pursued their own welfare at the expense of shareholders is unsustainable in the long term. This is because a company that was considered to be underperforming in the market in the long run would attract takeover bids to displace the management. 
The discussion so far is based on the organizational level of analysis. On the industry-level, Andrade et al. (2001: 108) argue that 'the industry shock explanation for mergers has added substantially to the understanding of mergers, not so much how they create value, but rather why and when they occur'. Andrade et al. (2001) argue that deregulation was a prominent industry shock in the period prior to the 1980s and has become a dominant factor in M\&A activity and continued to account for nearly half of the M\&A activity since then. In the same way, Mitchell and Mulherins (1996) posit that the structure of an industry, including the number and size of companies, is a function of factors of industry shocks such as technology, government policy and demand and supply conditions. Similarly, Harford (2005) and Gugler et al. (2005) also found specific industry shocks such as economic, regulatory and technological, to be causes of merger waves. However, Harford (2005) also argued that these shocks alone are insufficient to drive merger waves because capital available for investment will eventually drive them.

In the integrated studies of M\&A activities based on both organizational and industry levels, Mulherin and Boone (2001) show that companies restructured in response to industry shocks such as technology, input prices and deregulation, in the 1990s. Similarly, Klasa and Stegemoller (2007) examined changes in industry growth opportunities and their findings show that managers engaged in M\&A activities as a response to industry growth opportunities. By the same token, Blair and Schary (1993) investigated restructuring activity and based their study on the relationship between corporate performance and financial market behavior. However, they concluded that their model failed to explain restructuring activities between 1986 and 1989 and attributed that to 'a great many firm-specific, highly idiosyncratic factors [being] at work in addition to the industry-level and macroeconomic pressures we have identified' (Blair and Schary 1993: 184). Toxvaerd (2004) also studied the interactions between companies' intent and industry shocks to explain why mergers happen in waves and concluded that merger waves occur because of strategic interaction between exogenous economic conditions and the company. More importantly, Toxvaerd (2004) pointed out that each company was influenced differently by the same industry shocks, thus supporting the findings of Blair and Schary (1993) that there are company-specific factors involved. 
This review identifies a lack of literature in which M\&A activities are understood through the integration of two different levels: organizational- and industry-levels. Moreover, the methods used in these studies involved big sample sizes, leading to inconclusive results about M\&A performance. Given that M\&A activities stand out as an important agent of change with respect to companies and their industries, ascertaining the motives for M\&A activity should provide insights as to 'how' and 'why' specific companies expand whilst the understanding of industry shock could provide explanations for 'why' and 'how' M\&A happens (Andrade et al., 2001).

Table 3 presents a consolidation of the variables categorized under different motives (value and non-value maximization) and the commonly cited factors in industry shocks. These variables provide the framework for data collection and analysis to address the phenomenon under study in this paper.

Table 3: Summary of variables driving M\&A activities (developed for this study)

\begin{tabular}{|c|c|c|c|}
\hline \multirow{2}{*}{$\begin{array}{l}\text { Concepts } \\
\text { underpinning } \\
\text { assumptions }\end{array}$} & \multicolumn{2}{|c|}{ Organisational motives } & External environment \\
\hline & $\begin{array}{l}\text { Value maximization } \\
\text { motives (VMM) }\end{array}$ & $\begin{array}{c}\text { Non-Value } \\
\text { maximization motives } \\
\text { (NVMM) }\end{array}$ & Industry shocks (IS) \\
\hline $\begin{array}{l}\text { Variables } \\
\text { affecting the } \\
\text { achievement } \\
\text { of Value and } \\
\text { Non-value } \\
\text { maximizing } \\
\text { motives, and } \\
\text { industry } \\
\text { shocks }\end{array}$ & $\begin{array}{l}\text { Economies of scale and } \\
\text { scope (EoS\&S) } \\
\text { (Salter and Weinhold, 1979; } \\
\text { Teece, 1980; Singh and } \\
\text { Montgomery,1987; Häkkinen } \\
\text { et al. 2004; Barkema and } \\
\text { Schijven, 2008) } \\
\text { Market share (MS) } \\
\text { (Singh and } \\
\text { Montgomery,1987; Hitt et al., } \\
\text { 1998; Vermeulen and } \\
\text { Barkema, 2001; Gaughan, }\end{array}$ & $\begin{array}{l}\text { Managerial Welfare } \\
\text { (Marris, 1964; Jensen, } \\
\text { 1986; Berkovitch and } \\
\text { Narayanan, 1993; } \\
\text { Schoenberg, 2003) }\end{array}$ & $\begin{array}{l}\text { Deregulation (DeG) } \\
\text { (Mitchell and Mulherin, } \\
\text { 1996; Mulherin and } \\
\text { Boone, 2001; Andrade } \\
\text { et al., 2001; Harford, } \\
\text { 2005; Gugler et al., } \\
\text { 2005) }\end{array}$ \\
\hline
\end{tabular}




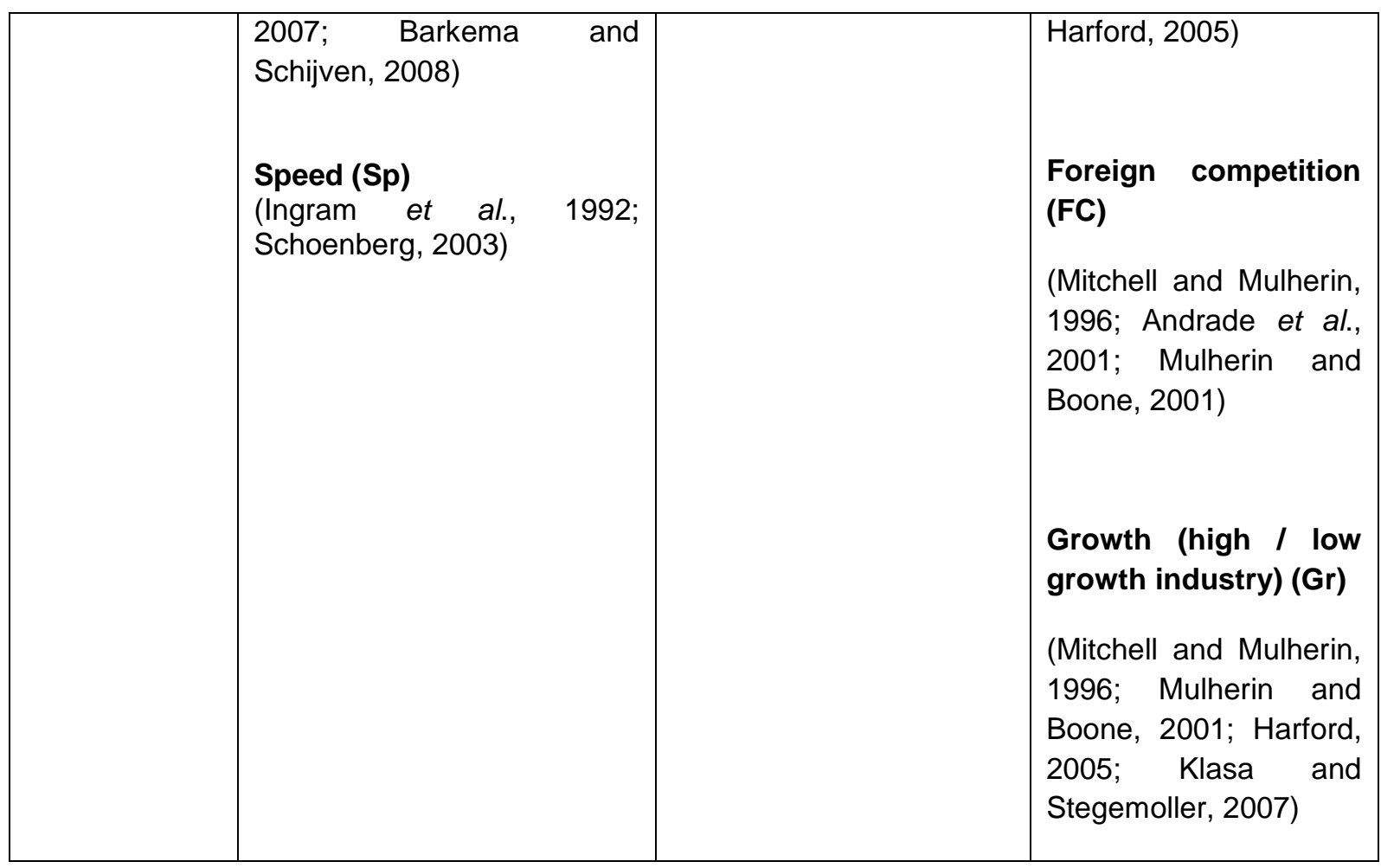

\section{Research methods}

To investigate the growth of four UK hotel companies and their expansions over 26 years, this study adopts a comparative historical analysis, suitable for carrying out this research for several reasons. According to Mahoney and Rueschemeyer (2003), the main feature of a comparative historical inquiry is predicated on the concern to identify causal configurations and this aspect is appropriate to this research as the occurrence of M\&A activities amongst hotel companies was evaluated by studying the interactions between organizational- and industry-levels. Moreover, comparative historical analysis stresses processes over time (Mahoney and Rueschemeyer, 2003), and this characteristic supports the longitudinal study whereby context is established and an uninterrupted picture of what happened over the period 1979 to 2004 is presented. In addition, comparative historical analysis emphasizes a systematic and contextualized comparison between a small number of cases within delimited historical contexts (Mahoney and Rueschemeyer, 2003). This feature is highly relevant to this research because a gap was found 
in M\&A studies whereby the ways in which company-specific factors affect the results of companies' performance is not identifiable when a large sample size is used. Furthermore, a comparative historical analysis is closely linked to an explanatory approach and this latter approach is considered useful to further develop existing concepts that have been much researched (Punch, 2000). Therefore, this study endeavors to further develop the study of M\&A activities, based on the strength of the explanatory approach and the adoption of qualitative and longitudinal techniques to answer the 'how' and 'why' questions.

The particular period between 1979 and 2004 has been selected for this paper because of changes in the UK macro environment and impacts from world events. Firstly, the UK economy experienced two economic booms and two economic slumps during this period. In the 1980s, the boom was led by the anticipation of the deregulation of the UK financial sector in 1986, and more funds being made available for investment. The establishment of the Single European market in 1992 also induced a high volume of M\&A activity within the UK (Garcia and TorreEncisco, 1995; Goergen and Renneboog, 2004). The two economic slumps occurring in the late 1980s and the late 1990s were results of the world economic slowdown. The UK economy was challenged by high inflation and interest rates between the late 1980s and the early 1990s. These events had a critical impact on the hotel industry. Secondly, this period is suitable for the purpose of this enquiry as competition in the UK hotel industry intensified with the entrance of foreign competitors. In the earlier periods (1960s and 1970s) of hotel development in the UK, the industry was dominated by two major players, namely Grand Metropolitan and Trust House Forte (Channon, 1978; Taylor and Bush, 1974). In contrast, from the 1980s, major hotel companies in the US and Asia were purchasing UK hotels because the US hotel companies wanted to expand internationally due to market saturation in their country while the Japanese companies were expanding because of their strong economic growth and a high balance of payment surplus, which enabled them to engage in M\&A activities outside Japan (Caterer and Hotelkeeper, 1986). 
Four hotel companies may be considered to represent a purposeful sample because the study of their development is able to draw out rich information and in-depth understanding and insight to illuminate the questions under study (Altinay and Paraskevas, 2008). Only four companies were selected for this study because these were leading UK hotel companies that grew speedily via M\&A activities in this period of study and became major international players via the acquisition of renowned international hotel brands (see Table 4). Each of these four companies is different in the nature of its original business, which corresponds with Yin's (2009) proposition that each case in multiple-case study research should provide a specific function within the overall scope of inquiry. In addition, these companies had developed over the years to become the largest hotel companies in the UK, by the number of rooms operated, as well as ascending in rank worldwide. The companies are Forte Group plc (hereafter known as Forte), InterContinental Hotels Group (hereafter known as Bass), Ladbroke Group plc (hereafter known as Ladbroke) and Whitbread Group plc (hereafter known as Whitbread). Equally important, these are publicly listed companies, which enabled the collection of information through public sources, addressing a key limitation of this study.

Table 4: Companies' histories in brief

\begin{tabular}{|c|c|}
\hline Companies' histories & UK and world ranking (based on number of hotel rooms) \\
\hline $\begin{array}{l}\text { Forte Group plc (Forte / Forte Hotels) } \\
\text { Forte Holdings Ltd was founded by Charles Forte ( later } \\
\text { Lord Forte) in } 1935 \text {. The business grew from operating a } \\
\text { milk bar in London's West End to operating hotels and } \\
\text { catering businesses. The first hotel was bought in } 1958 \\
\text { and the Group continued to expand through organic and } \\
\text { M\&A activities. The Group bought the Le Meridien hotel } \\
\text { group in } 1994 \text { and gained an international hotel brand } \\
\text { name. Forte was taken over by the Granada group in } \\
1996 .\end{array}$ & $\begin{array}{l}\text { Ranked as the top UK hotel company operating the most } \\
\text { hotels and hotel rooms from } 1979 \text { to } 1996 \text {. Forte started its } \\
\text { internationalization strategy in the late } 1960 \text { s with the } \\
\text { purchase of three five-star hotels in Paris, (George V, Plaza } \\
\text { Athenee and Tremoille) } \\
\text { Ranked top ten and eleventh worldwide between } 1983 \text { and } \\
1994 \text {. The number of rooms decreased rapidly and its ranking } \\
\text { fell from } 9 \text { to } 14 \text { between } 1994 \text { and } 1995 \text { due to the sales of } \\
\text { hotel properties in defense against a hostile take-over by the } \\
\text { Granada Group plc. }\end{array}$ \\
\hline $\begin{array}{l}\text { M\&A activities: } \\
\text { 1981 - The Savoy Hotel (majority shares without } \\
\text { controlling rights) } \\
1986 \text { - Anchor Hotels } \\
1988 \text { - Kennedy Brookes } \\
1990 \text { - Crest Hotels } \\
1994 \text { - Le Meridien Hotels }\end{array}$ & \\
\hline $\begin{array}{l}\text { The Ladbroke Group plc (Ladbroke / Hilton International) } \\
\text { The Ladbroke Group plc was founded in } 1886 \text { and floated } \\
\text { as a gaming company in1967. Ladbroke entered the hotel }\end{array}$ & $\begin{array}{l}\text { Ranked between second and sixth in the years } 1983 \text { to } 2004 \text {, } \\
\text { in terms of number of hotels operated in the UK. Ladbroke } \\
\text { embarked into international expansion in } 1984 \text { with the } \\
\text { purchase of Comfort Hotels (located in the UK and Europe) }\end{array}$ \\
\hline
\end{tabular}




\begin{tabular}{|c|c|}
\hline $\begin{array}{l}\text { industry in } 1973 \text { and expanded its hotel sector through } \\
\text { M\&A activities from the 1980s. The Group bought Hilton } \\
\text { International in 1987, thus gaining the brand name for all } \\
\text { Hilton hotels operated outside North America, and } \\
\text { became a leading international hotel operator. From } \\
\text { 1994, Ladbroke sold its other business units to } \\
\text { concentrate on its hotel and gaming businesses. } \\
\text { M\&A activities: } \\
1979 \text { - Myddleton Hotels } \\
1984 \text { - Comfort Hotels } \\
1985 \text { - Rodeway Inn Hotels } \\
1987 \text { - Hilton Hotels } \\
1999 \text { - Stakis Hotels } \\
2001 \text { - Scandic Hotels }\end{array}$ & $\begin{array}{l}\text { and Rodeway Inn Hotels (in USA). } \\
\text { Ladbroke's ranking ascended from the position of } 113 \text { in } 1986 \\
\text { to } 23 \text { worldwide after the acquisitions of Comfort Hotels (in } \\
1984 \text { ) and Rodeway Inns (in 1985). The Group made it to } \\
\text { position } 17 \text { after the purchase of HHI in } 1987 \text { and was ranked } \\
\text { among the top } 15 \text { worldwide in subsequent years. }\end{array}$ \\
\hline $\begin{array}{l}\text { Bass Group plc (Bass / Intercontinental Hotel Group } \\
\text { (IHG)) } \\
\text { Bass started its brewery business in } 1777 \text { and grew its } \\
\text { hotel business through M\&A activities from the 1960s. } \\
\text { Bass's major acquisition was the Holiday Inn hotel group } \\
\text { from the mid 1980s; the Group became a leading } \\
\text { international hotel operator. Bass sold its original brewing } \\
\text { business in } 1999 \text { to concentrate on expanding its hotel } \\
\text { and drink businesses. } \\
\text { M\&A activities: } \\
1979 \text { - Clingendael Hotel Group } \\
1980 \text { - Centre Hotels } \\
1985-1989 \text { - Holiday Inn } \\
1998 \text { - InterContinental Hotels } \\
2000 \text { - Southern Pacific Hotels Corporation } \\
2000 \text { - Bristol Hotels \& Resorts } \\
2001 \text { - Post House } \\
2003 \text { - Candlewood Suites }\end{array}$ & $\begin{array}{l}\text { Ranked between second and eighth positions between } 1983 \\
\text { and } 2000 \text { in the UK, and became the first or second in terms of } \\
\text { the number of rooms between } 2001 \text { and } 2004 \text {. } \\
\text { Ranked in the first and second position worldwide between } \\
1983 \text { and } 2004 \text {. }\end{array}$ \\
\hline $\begin{array}{l}\text { Whitbread plc (Whitbread) } \\
\text { Whitbread's brewery business began in } 1742 \text { and it } \\
\text { entered the hotel business in the early 1970s. The Group } \\
\text { continued to expand its hotel business through organic } \\
\text { growth and only engaged in hotel M\&A activities from } \\
\text { 1995, with the acquisition of the brand right to operate all } \\
\text { Marriott Hotels in the UK. In 1999, Whitbread sold its } \\
\text { original brewing business to concentrate on expanding its } \\
\text { hotel, restaurant and health and fitness businesses. } \\
\text { M\&A activities: } \\
1995 \text { - Marriott Hotels (brand rights in the UK) } \\
1999 \text { - Swallow Hotels } \\
2004 \text { - Premier Lodge }\end{array}$ & $\begin{array}{l}\text { Ranked above the } 30^{\text {th }} \text { position between } 1983 \text { and } 1987 \text { in the } \\
\text { UK. The Group's ranking in the UK moved up to } 10^{\text {th }} \text { position } \\
\text { in } 1992 \text { and it became top hotel company in } 2004 \text { (largest } \\
\text { budget hotel operator in the UK). Whitbread's first venture into } \\
\text { the international hotel market was the acquisition of rights to } \\
\text { be the sole operator of the Marriott brand in the UK. } \\
\text { Whitbread was ranked in the top } 200 \text { between } 1983 \text { and } 1996 \text {, } \\
\text { and made it to the top } 100 \text { from } 1994 \text {, based on its leadership } \\
\text { as the budget hotel hotels provider and the acquisition of the } \\
\text { sole operating rights to the Marriott brands in the UK. The } \\
\text { Group was ranked in the top } 50 \text { worldwide in terms of the } \\
\text { number of rooms in } 2004 \text {. }\end{array}$ \\
\hline
\end{tabular}

Source: Various newspapers, trade journals, annual reports of Bass, Ladbroke and Whitbread (1979 - 2005); annual reports of Forte (1979 - 1996); British Hotel Association (2000 - 2004); Goymour (1987 - 1994); Goymour and Chitty (1986); Hotel (1990 - 2005); Hotel \& Restaurant International (1984 - 1989) 
One limitation in this research design lies in the lack of access to archival documents such as company meeting minutes, memos and letters between executives. Moreover, attempts to gain access to executives of hotel companies were unsuccessful and the research method shifted to concentrate on secondary data collection and analysis. Although the data in the companies' archive and interviews with executives would have been useful for this study with regard to M\&A activities, the main difficulty in accessing these documents and the executives was also caused by the companies having gone through several M\&A and restructuring activities. This change in research design has not compromised the quality of this study; rather, it has reinforced the dynamic nature of these companies and their relevance as the sample for this study on the development and changes of companies and industry through M\&A activity itself.

This study is carried out by using a wide range of secondary data retrieved from the Internet and paper publications. Publications about hotel companies in particular and the hotel industry and external environmental issues in general were reviewed through a number of databases such as Business Source Premier, Emerald, Euromonitor, Hospitality and Tourism Database, Key Notes and Mintel. Data and relevant articles were also retrieved from the Bodleian Library, City Business Library, Colindale Newspaper (The British Library), Companies House, New York Public Library, Oxford Brookes' Library and The British Library. Several websites such as Bank of England, British Hospitality Association, Compass Group plc, Competition Commission, Department of Trade and Industry, European Union, Gambling Commission, Hilton Group plc, InterContinental Hotels Group, National Statistics, VisitBritain.com and Whitbread Group plc were used.

In this paper, the multiple secondary sources available made it possible to collect data from a variety of sources regarding the same phenomenon - development of four hotel companies - at the same time validating one source of information against another. For example, data retrieved from company annual reports, newspapers and trade journals can help in scrutinizing explanations of motives for a particular deal from the company's perspective. Simultaneously, the comments made regarding the same deal by industry-specific analysts in newspapers and 
trade journals can confirm, refute or provide more insight into comments the company made regarding that deal. More importantly, comments retrieved from different sources pertaining to that particular period helped to put individual transactions into context.

The analysis of this paper was predicated on four steps proposed by Saunders et al., (2007: 479): categorizing, unitizing data, recognizing relationships and developing the categories to facilitate this and developing and testing theories to reach conclusions. In this research, the first step was reviewing M\&A literature, categorizing variables and building the theoretical framework (see Table 3). This framework was used as a point of reference for data collection and documenting the four cases.

The second step of 'unitizing data' involved identifying variables in secondary data which classified relevant data according to the motives stated in the framework. Data units are sentences (see Table 5) and variables are attached to data units. Analysis of data was first carried out by identifying words that are identical or closely related to a given expression. For example, terms including 'cost cutting', 'cross-selling' and 'increase size' are linked to economies of scale and scope and sought in sentences, as a means of informing readers about the motives for the particular M\&A deal. Information extraction started with one company by reading materials retrieved on a year by year basis to extract general information pertaining to each M\&A deal. The data is then presented in a chronological order.

Table 5: Newspaper article extract with variables attached (Example: Bass bought Holiday Inns)

\begin{tabular}{|c|c|}
\hline Variables & Newspaper article extract \\
\hline $\begin{array}{l}\text { Similar product, increase } \\
\text { in size and market share } \\
\text { via re-branding. }\end{array}$ & $\begin{array}{l}\text { Bass, Britain’s biggest brewer is paying £297 million for a chain of } 178 \\
\text { Holiday Inns as part of a big expansion of its hotel interest. } \\
\text { The deal gives Bass control of the Holiday Inns operation worldwide outside } \\
\text { the United States, Canada and Mexico. Bass already owns } 117 \text { hotels in } \\
\text { Britain and Europe - some of which will be changed over to Holiday Inns - } \\
\text { and now becomes a large force in the business. } \\
\text { But Mr lan Prosser, the managing director of Bass insisted the acquisition }\end{array}$ \\
\hline
\end{tabular}




\begin{tabular}{|l|l|}
\hline Non-managerial motive. & $\begin{array}{l}\text { was not intended to compensate for the failure to buy the Hilton hotel chain } \\
\text { which was sold to Ladbroke for } £ 645 \text { million two weeks ago. } \\
\text { "This deal is quite different and is a continuation of an arrangement we } \\
\text { reached earlier this year with Holiday Corporation - the master company - } \\
\text { when we acquired a group of eight Holiday Inns in Europe" he said. } \\
\text { The latest agreement, which will be completed in the first quarter of next } \\
\text { year, involves the purchase of } 13 \text { hotels in the southern states of the US } \\
\text { and the right to run } 165 \text { hotels around the world. }\end{array}$ \\
Speed; increase in size. & \\
\hline
\end{tabular}

Source: Article adapted from Feltham (1987b)

The third step of 'recognizing relationships and developing categories' is conducted via the analysis of the four cases on a case-by-case basis. In this study, the relationship between theory and data is first recognized by comparing motive(s) retrieved from secondary data, and analyzing them against the motives for M\&A activities of one hotel company. This way of analyzing each transaction against theory was repeated for every single deal closed in the other three case companies (see Table 4). The next step was to integrate the context, in the form of industry shocks, and this constant comparison between theory and data, and the iterative process, also helped to improve accuracy and reliability in the analyses and conclusions.

The final step of 'developing and testing theories to reach conclusions' in this analysis is conducted by seeking patterns of similarities or differences across the four cases, in terms of current variables in the theoretical framework, as well as variable(s) newly discovered during the previous step of identifying the relationships between existing theory and data. In this paper, a cross-case comparison dissects the four cases through the discussion of variable(s) that supported or did not support the literature. Variable(s) that do not conform to parts of the framework will be evaluated to provide alternative explanations. 


\section{Findings and discussion}

This section discusses the findings, based on the interactions between organizational motives and external environmental factors to shed light on the M\&A activities of these four hotel companies. Dealing with each M\&A activity individually serves the purpose of tracing causal events, not only about the deal involved, but also in terms of a link between M\&A deals, as well as between deals and the industry-specific events occurring concurrently in the external environment, over a delimited period of time. It is found that the motives for M\&A activities in these hotel companies support the M\&A value maximization motives: economies of scale and scope, market share and speed (see Table 6). Non-value maximizing reasons such as managers' focus on growing company size, rather than profit, found in this study do not concur with the literature. Factors proposed in the industry shocks literature such as financial deregulation, technology development, foreign competition and industries' growth and decline are also supported by this study. Under 'other motives', brand acquisition, risk averseness and knowledge acquisition were recurring themes found in this study.

Table 6: Motives found in this study

\begin{tabular}{|l|l|l|l|l|l|l|l|l|}
\hline & \multicolumn{2}{|c|}{$\begin{array}{c}\text { Value Maximizing } \\
\text { motives }\end{array}$} & $\begin{array}{l}\text { Other } \\
\text { Motives* }\end{array}$ & \multicolumn{3}{c|}{ Industry shocks } \\
\hline & $\begin{array}{l}\text { EoS } \\
\text { \&S }\end{array}$ & MS & Sp & & Gr & Tech & DeG & FC \\
\hline $\mathbf{1 9 7 9}$ & & & & & & & & \\
\hline Bass / Clingendael & & $\checkmark$ & $\checkmark$ & & & & & \\
\hline Ladbroke / Myddleton & $\checkmark$ & $\checkmark$ & $\checkmark$ & & $\checkmark$ & & & \\
\hline $\mathbf{1 9 8 0}$ & & & & & & & & \\
\hline Bass / Centre & $\checkmark$ & $\checkmark$ & & $\checkmark$ & $\checkmark$ & & & \\
\hline $\mathbf{1 9 8 1}$ & & & & & & & & \\
\hline Forte / The Savoy & $\checkmark$ & $\checkmark$ & & $\checkmark$ & & & & \\
\hline $\mathbf{1 9 8 4}$ & & & & & & & & \\
\hline Ladbroke / Comfort & $\checkmark$ & $\checkmark$ & $\checkmark$ & & $\checkmark$ & $\checkmark$ & $\checkmark$ & $\checkmark$ \\
\hline $\mathbf{1 9 8 5}$ & & & & & & & & \\
\hline $\begin{array}{l}\text { Bass / Holiday Inn } \\
\text { 1985-1989 }\end{array}$ & $\checkmark$ & $\checkmark$ & $\checkmark$ & $\checkmark$ & $\checkmark$ & $\checkmark$ & & $\checkmark$ \\
\hline Ladbroke / Rodeway Inn & $\checkmark$ & $\checkmark$ & $\checkmark$ & $\checkmark$ & & & & \\
\hline $\mathbf{1 9 8 6}$ & & & & & & & & \\
\hline
\end{tabular}




\begin{tabular}{|l|l|l|l|l|l|l|l|l|}
\hline Forte / Anchor & $\checkmark$ & $\checkmark$ & $\checkmark$ & $\checkmark$ & $\checkmark$ & $\checkmark$ & $\checkmark$ & $\checkmark$ \\
\hline $\mathbf{1 9 8 7}$ & & & & & & & & \\
\hline Ladbroke / Hilton & $\checkmark$ & $\checkmark$ & $\checkmark$ & $\checkmark$ & $\checkmark$ & $\checkmark$ & $\checkmark$ & $\checkmark$ \\
\hline $\mathbf{1 9 8 8}$ & & & & & & & & \\
\hline Forte / Kennedy Brookes & $\checkmark$ & $\checkmark$ & & $\checkmark$ & $\checkmark$ & $\checkmark$ & $\checkmark$ & $\checkmark$ \\
\hline $\mathbf{1 9 9 0}$ & & & & & & & & \\
\hline Forte / Crest & $\checkmark$ & $\checkmark$ & $\checkmark$ & & $\checkmark$ & $\checkmark$ & $\checkmark$ & $\checkmark$ \\
\hline $\mathbf{1 9 9 4}$ & & & & & & & & \\
\hline Forte / Le Meridien & $\checkmark$ & $\checkmark$ & & $\checkmark$ & $\checkmark$ & $\checkmark$ & $\checkmark$ & $\checkmark$ \\
\hline $\mathbf{1 9 9 5}$ & & & & & & & & \\
\hline Whitbread / Marriott & $\checkmark$ & $\checkmark$ & $\checkmark$ & $\checkmark$ & $\checkmark$ & $\checkmark$ & $\checkmark$ & $\checkmark$ \\
\hline $\mathbf{1 9 9 8}$ & & & & & & & & \\
\hline Bass / InterContinental & $\checkmark$ & $\checkmark$ & $\checkmark$ & $\checkmark$ & $\checkmark$ & $\checkmark$ & $\checkmark$ & $\checkmark$ \\
\hline $\mathbf{1 9 9 9}$ & & & & & & & & \\
\hline Ladbroke / Stakis & $\checkmark$ & $\checkmark$ & $\checkmark$ & $\checkmark$ & $\checkmark$ & $\checkmark$ & $\checkmark$ & $\checkmark$ \\
\hline Whitbread / Swallow & $\checkmark$ & $\checkmark$ & $\checkmark$ & & $\checkmark$ & $\checkmark$ & $\checkmark$ & $\checkmark$ \\
\hline $\mathbf{2 0 0 0}$ & & & & & & & & \\
\hline $\begin{array}{l}\text { Bass / Southern Pacific } \\
\text { Hotels Corporation }\end{array}$ & $\checkmark$ & $\checkmark$ & $\checkmark$ & $\checkmark$ & & $\checkmark$ & & $\checkmark$ \\
\hline $\begin{array}{l}\text { Bass / Bristol Hotels \& } \\
\text { Resorts }\end{array}$ & $\checkmark$ & $\checkmark$ & $\checkmark$ & $\checkmark$ & & $\checkmark$ & & $\checkmark$ \\
\hline $\mathbf{2 0 0 1}$ & & & & & & & & \\
\hline Bass / Post House & $\checkmark$ & $\checkmark$ & $\checkmark$ & & & & & $\checkmark$ \\
\hline Ladbroke / Scandic & $\checkmark$ & $\checkmark$ & $\checkmark$ & $\checkmark$ & $\checkmark$ & $\checkmark$ & & $\checkmark$ \\
\hline $\mathbf{2 0 0 3}$ & & & & & & & & \\
\hline $\begin{array}{l}\text { Bass / Candlewood } \\
\text { Suites }\end{array}$ & $\checkmark$ & $\checkmark$ & $\checkmark$ & $\checkmark$ & & $\checkmark$ & & $\checkmark$ \\
\hline $\mathbf{2 0 0 4}$ & & & & & & & & \\
\hline $\begin{array}{l}\text { Whitbread / Premier } \\
\text { Lodge }\end{array}$ & $\checkmark$ & $\checkmark$ & $\checkmark$ & & & $\checkmark$ & & $\checkmark$ \\
\hline brand acquition, rsk avers & & & & & & & \\
\hline
\end{tabular}

*brand acquisition, risk averseness and knowledge acquisition.

M\&A activities in the hotel industry could not have taken place without financial support, either from the company itself or other sources, because of the nature of their high capital cost. This concurs with the assumptions made by Harford (2005) and Gugler et al. (2005) who argued that capital available for investment is crucial in the industry shock literature. UK financial deregulation in 1986 was a major shock for the hotel industry, helping to generate more funds made available by local and foreign financial institutions in the UK. This benefited hotel companies by allowing them easier access to capital, considering how capital intensive this industry is. Funds were made available for expansion, in the form of bank loans with competitive interest rates and / or money generated from the share market and / or insurance companies and building societies (Ennew et al., 1990; Jeremy, 1998; Reid, 1988). 
The technological shock is particularly pertinent for the hotel industry as international trade barriers across borders began to disappear and mobility of visitors between national borders increased. IT enables quick dissemination of information and so enhances sales and marketing, as well as the management and operation systems of hotel units across borders. This view is supported by several M\&A deals closed, such as Whitbread - Marriott, Bass - Holiday Inn, Ladbroke - Hilton and Forte - Le Meridien. These companies adopted the cost cutting factor derived from economies of scale, when rooms from two different companies were integrated after M\&A activities into the same computer reservation system. Economies of scope are also achievable by cross selling a range of different products, such as hotel rooms, at different market levels or located in different geographical regions and countries through the same computer reservation system. Thus, this study also supports several authors' suggestions that technology is one of the major industry shocks (Harford, 2005; Mulherin and Boone, 2001; Toxvaerd, 2004). These findings also supported the view that sharing of specialized know-how can realize economies of scope (Teece, 1980). For instance, the motive of gaining knowledge and expertise for operating international companies via franchising was demonstrated by the acquisitions of Holiday Inns by Bass in 1985 and Rodeway Inns by Ladbroke in 1985. Neither company had prior experience in operating franchising systems at that time. In addition, Ladbroke's and Bass's acquisitions of Hilton hotels and InterContinental hotels in 1987 and 1998 respectively also contain the motive of acquiring management contracting knowledge. This in turn suggests the intensifying nature of foreign competition driven by globalization, and evidences the interdependent relationship between companies' motives and industry shocks concepts.

Strategic motives that aim to increase market share and reach new markets quickly are also apparent in these deals, supporting Ingram et al.'s (1992) and Schoenberg's (2003) suggestion that M\&A activity provides a much faster means of growth as compared with organic growth. The lengthy building process, a lack of land, difficulties in obtaining planning permission and intensifying competition (Caterer and Hotelkeeper, 1986), in conjunction with the need to expand quickly to meet rising demand, within the UK and worldwide, made M\&A activities an indispensable survival requirement in a competitive hotel industry. This is evident from Forte's 
purchases of Anchor, KB and Crest; Bass's acquisitions of Centre and Post House; Ladbroke's acquisitions of Comfort and Stakis; and the three deals closed by Whitbread. All these transactions were intended to expand geographical presence as well as to increase market share quickly via converting and re-branding existing hotels.

This study also supports the view that industry shocks such as an industry's growth or decline drive M\&A activities (Andrade et al., 2001; Mitchell and Mulherin, 1996). For example, deals closed by Bass in the 1980s (Holiday Inns) and 2001 (SPHC and BH\&R), and those closed by Whitbread in 1995 (Marriott) and 1999 (Swallow) were linked to the aim of expanding into a growth industry, the hotel industry, to reduce their companies' exposure to the declining brewing industry [2]. Unlike Forte and Ladbroke, these companies had not come into the hotel business via the historical path of brewing. Thus, M\&A activities are dependent on company specific motives as well as industry shocks, which also supports the view of Blair and Schary (1993), Gulger et al. and Toxvaerd (2004) that there are company-specific reasons interacting with industry shocks.

As to non-value maximizing motives, this study does not support the literature regarding the managerial motive, such as managers engaging in M\&A activities for the sake of growth in company size, rather than profit, or managers seeking the prestige of running a big company when the company expands (Berkovitch and Narayanan, 1993; Jensen and Meckling, 1976; Marris, 1964). This can be explained by an indicator of shareholder value - namely earnings per share (EPS) - and the increasingly active shareholders in the financial institutions who monitored management and company financial performance. EPS for all the sample companies were declining between 1991 and 1992 and in the early 2000s. For example, EPS declined between 4\% and 83\% in the period between 1991 and 1992 (A/R Bass, 1992; A/R Ladbroke, 1992; A/R THF 1992; A/R Whitbread, 1992). Although these hotel companies had acquired other hotel companies before 1990 (Ladbroke-Hilton International in 1987; THF-Kennedy in 1988; and Bass-Holiday Inns from 1985 - 1990; Whitbread has no hotel acquisition activities until 1995), the negative impacts they experienced were not directly linked to their hotel acquisition, but to external environmental factors. 
Ladbroke's EPS saw a much smaller decline between the two critical periods: -62\% (1991-1992) and -7\% (2001-2002) (A/R Ladbroke, 1992; 2002). The huge improvement for Ladbroke was a result of the company's response to external crisis and corporate strategic change. In the late 1980s, the UK economy was challenged by rising unemployment and high inflation and interest rates, leading to decreasing demand for new buildings and higher building costs (Scott, 1996). This adverse effect spilled over into the hotel industry, which, like the property market, experienced a reduction in demand and an increase in servicing debt interest. Ladbroke decided to sell its property division in 1994 . In the early 2000s, despite the world economic downturn, Ladbroke's financial performance was improved by a change in gambling taxation [3].

The aftermath of the early 1990s economic crisis also saw Whitbread rationalizing its hotel division by selling its three-star Lansbury hotel group and THF reducing debt to maximize profit by disposing of the group's underperforming assets and non-core businesses. Bass, on the other hand, was not as severely affected as the other three companies because it had reduced its ownership of hotel assets and expanded via franchising, since buying the Holiday Inns hotels in the 1980s. Similarly, the more difficult market conditions in the early 2000s (Forte was taken over in 1996), a result of the combination of worldwide recession, the 9/11 terrorist attack in New York, diseases such as Severe Acute Respiratory Syndrome (SARS) and the Afghanistan and Iraq wars, had an adverse impact on Whitbread and Bass. Both companies saw a decline in overall operating profits, contributed to by their sales of brewing divisions in 2000 (AR / Bass, 2001; AR / Whitbread, 2000 / 01).

The analysis supports the argument that the longitudinal approach and an integration of M\&A activities at two levels afford better understanding of why and how these hotel companies engaged in hotel acquisitions. It also shows how companies responded to external environmental changes to adapt their strategies for corporate survival and growth by streamlining their different businesses. Moreover, they show how motives of value maximization prevail whilst non-value maximizing motives were not supported when analyzed against the M\&A literature. In addition, this study does not support the argument for the ability 
of shareholders to monitor management decline as the corporation grows larger and more complex (Jensen, 1986). In the case of UK hotel companies, the pressures exerted by analysts in the City and shareholders in financial institutions controlled management capital investment decisions. This is most prominent in the case of Bass's shareholders and its management in 2001. The shareholders warned the management against bidding for either Wyndham International or Starwood Hotels and Resorts, even before the management could action such aspirations, and demanded, as dividend returns, capital derived from the brewery sales in 2000 (Dickson, 2002).

One significant recurring theme found in this study is the aim to buy a brand name or brand right. This motive has not been specifically discussed in the general M\&A literature. The fact that 'brand as a motive for acquisition' has been neglected could be linked to the limited M\&A studies conducted in the hotel industry. It is found that under international competitive conditions, there arises the need to possess an international brand name to grow and survive. The ownership of a brand name enables hotel companies to expand quickly by re-branding existing hotels; this fits in with the inherent nature of hotel business which needs to be physically present in different locations to be consumed. Risk averseness was also commonly found in this study which shares a common thread with brand acquisition. A well-known brand name enables hotel companies to reduce capital investment, thus lowering the level of risk taken, by using the brand name to engage in management contracting and franchising to expand their companies. The importance of brand acquisition was evidenced in the 1990s when the motive to acquire branded hotel companies, in the case of Bass-SPHC and Bass-BH\&R, was to overcome difficulties in winning management contracts and to gain speed in entering growth markets (the Asia Pacific region, in particular), further reflecting the intensifying competition worldwide. Consequently, the knowledge acquired in conjunction with the ownership of brand name and brand right became a core set of domestic and international expansion strategies. 


\section{Conclusion}

The aim is to understand why M\&A activity is widely used as a means for expansion whilst the success rate is low, as noted by previous studies in this area of research. It is contended that there is a gap in these studies due to the methods used, involving large sample sizes and / or mixtures of industries, leading to inconclusive results for M\&A performance. Therefore, this paper utilized a combination of a single industry, small sample size and a longitudinal approach to address this gap. The findings support the value maximizing motives and contradict the nonvalue maximizing motives. This study also shows that industry shocks such as financial sector deregulation, technological change, the brewing industry's decline, hotel industry growth, property value fluctuation, and foreign competition were drivers of M\&A activities.

Comparative historical analysis is useful as a method to highlight the multi-level analysis of companies' internal motives and external environmental interactions in a longitudinal approach, in turn, illustrating the limitations of existing large sample size and multi-industry studies. More important is, to address the research question and reveal that this kind of interdisciplinary research can show that these hotel companies did succeed in each M\&A deal, in terms of achieving their objectives, evident from the longitudinal analysis of their financial reports. Moreover, this interdisciplinary approach revealed management organizational capabilities which recognize opportunities (hotel growth) and address external environmental changes (decline in property value and consumer demand for beer), using appropriate strategies to improve their company and add shareholder value. Equally important, the longitudinal study also shows that declines in these companies' financial returns were mainly due to external factors such as economic crisis and world events. This in turn supports Barkema and Schijven's (2008) and Lubatkin's (1983) view that the performance of companies going through a string of M\&A activities becomes apparent only after many years of the recombination of subunits to reduce organizational inefficiencies.

This study also revealed that 'brand motive' is an independent variable, particularly in the hotel industry, but has been neglected as a variable in the literature of M\&A activities. The 1980s 
onwards saw growth in M\&A via brand name and brand rights acquisition amongst UK hotel companies which had previously emphasized holding assets and / or a strong balance sheet. Adoption of franchising and management contracting requires minimum to no equity investment. The inherent power of brand names became an essential mechanism for corporate strategy as it played an important role in the ability to command price and market power. For instance, Bass increased its franchising fees after completing its acquisition of the Holiday Inn brand worldwide. The Canadian company, Scott's Hospitality, which was unable to obtain the exclusive Master franchise rights to operate all Holiday Inn brands in the UK decided to withdraw its franchising contract with Bass in 1990, instead, re-branding its UK hotels as Marriott.

\section{Implications for practitioners}

This longitudinal study of acquisition motives - enjoying economies of scale, increasing market share quickly and brand acquisition via the purchases of hotel groups which complement or supplement each purchaser's geographical or market share - shows a high success rate evident in financial performance, as well as the instant physical presence worldwide. This evidence serves as useful information for practitioners to identify the type of target companies for selection in order to expect a more successful M\&A transaction; these include horizontal acquisitions, particularly of companies that share similar resources or end products in two ways.

The development of UK hotel companies over 26 years also bears witness to the usefulness of M\&A activities, particularly in the acquisition of brand names, highlighting the fact that ownership

of a respected brand name will continue to expedite growth in tandem with reduced financial risks in a competitive global environment. It also illuminates the positive performance of M\&A activities in the hotel industry after the many years of recombinations of subunits needed to reduce organizational inefficiencies. Thus, the results of this longitudinal study of M\&A activities 
and the subsequent strategic changes that led to the survival and growth of these hotel companies may help current practitioners to use the past to inform the present and future.

\section{Further research}

Firstly, there is no comprehensive analysis of how and why hotel companies expanded using M\&A activities (see Table 1 and Table 2). This gap is related to the fact that access to companies was difficult to gain, leading to few attempts to undertake studies in this area. To compound the complication of the research process in the area of M\&A activities, the companies studied closed several transactions over the years, and sensitive issues of deal agreement and the complicated process of re-structuring within companies (jobs kept and job losses) could be on-going as the author studied these deals. Thus, it was no surprise that access was denied and company documents were not released for public or research purposes. On the other hand, secondary data is a useful source, as this paper has shown. Nonetheless the data analysis, particularly the synthesis of companies' annual financial performance over time in conjunction with the external environment supports the reasons announced for engaging in M\&A activities. Furthermore, the evaluation of multiple cases increased the breadth (general factors in the growth of the industry and whole economy) and depth (contextual conditions of business development) of this research. Further research could expand the number of hotel companies being studied as well as replicate this research method and apply it in other countries.

The focus of this study has been on the value of understanding the motives for M\&A activities through interactions between organizational and industry levels in the UK hotel industry. Different countries possess different environmental factors, such as political ideologies, legislation, economic performances and cultural perspectives: thus, country-specific industry shocks emerge differently. Therefore, it is impossible to enumerate all possible organizational motives and external factors in this study and future research may include more different motives and external factors to extend knowledge. 
A further agenda of extending the historical period studied to trace developments back and forward in time, could also add insights into structural changes in the hotel industry in particular and tourism industries in general. This paper takes a small step in the direction of examining M\&A activities by the integration of historical data, management theory and a qualitative approach to understanding hotels' historical expansion. It is hoped that this work could stimulate interest and provoke arguments for further research in and contribution to the historical study of the hotel industry.

\section{Note:}

[1] Mergers and acquisitions are used interchangeably in this paper despite the different meanings each word entails. 'Merger' is generally linked to a union between two or more companies (percentage of ownership differing or equally distributed) whilst 'acquisition' usually refers to one company buying another and the latter might or might not be merged into the acquiring company subsequently.

[2] Under the Beer Orders, a law enacted in 1989, breweries that owned more than 2,000 pubs were forced to sell their excess properties by November 1, 1992 (House of Commons, 2004). This decision was aimed at reducing the monopoly power of the 'Big Six' - Whitbread plc, Bass plc, Allied-Lyons plc, Grand Metropolitan plc, Scottish \& Newcastle plc and Courage, a unit of Australia's Foster's Brewing Group Ltd, who were controlling about $77 \%$ of the market (House of Commons, 2004). Bass and Whitbread sold their brewing businesses to focus on hotel businesses in the late 1990s due in part to the decline in beer consumption and restricted growth imposed by the Beer Orders of 1989. Moreover, each company was stopped from expanding its brewing division through M\&A in the brewing industry. Bass's merger with Carlsberg -Tetley in 1997 was stopped by Board of Trade on competition grounds (AR/ Bass, 1997) and Whitbread's attempt to acquire the Allied Domecq pub estate in 1999 was being given attention by the Office of Fair Trade (AR/ Whitbread, 1999). 
[3] Gradual relaxation of gaming rules from 1996, and the abolition of the $9 \%$ consumer tax on betting which was replaced by a 15\% Gross Profit Tax on gaming operators' gross profits in 2002, in conjunction with the emergence of online betting stimulated by the availability of cheap, fast Internet access (Mintel, 2005a; 2006) contributed to the better financial performance in Ladbroke's gaming division. 


\section{References}

Altinay, L. and Paraskevas, A. (2008), Planning research in hospitality and tourism, ButterworthHeinemann, Oxford

Andrade, G., Mitchell, M. and Stafford, E. (2001), 'New Evidence and Perspectives on Mergers', Journal of Economic Perspective, Vol. 15, No. 2, Spring, pp. 103 - 120

AR/ Bass (1979 - 2000), Annual Report and Financial Statements, Bass plc, UK

AR/ Bass (2001 - 2002), Annual Report and Financial Statements, Six Continents plc, UK

AR/ Bass (2003 - 2005), Annual Report and Financial Statements, Intercontinental Group plc, UK

AR/ Ladbroke (1979 - 1998), Annual Report and Financial Statements, Ladbroke plc, UK

AR / Ladbroke (1999 - 2005), Annual Report and Financial Statements, Hilton Group plc, UK

AR/ Forte (1979 - 1990), Annual Report and Financial Statements, Trusthouse Forte plc, UK

AR/ Forte (1991 - 1996), Annual Report and Financial Statements, Forte plc, UK

AR/ Whitbread (1979 - 2005), Annual Report and Financial Statements, Whitbread Group plc, UK

Arbel, A. and Woods, R. H. (1988), Shark Repellent: Anti-Takeover Measures for the Hospitality Industry, Cornell Hotel \& Restaurant Administration Quarterly, December, Vol. 29, Issue 3, pp. 28-39

Barkema, H. G. and Schijven, M. (2008), 'Toward unlocking the full potential of acquisitions: the role of organizational restructuring', Academy of Management Journal, August, Vol. 51, No. 4, pp. $696-722$ 
Berkovitch, E. and Narayanan, M. P. (1993), 'Motives for takeovers: An Empirical Investigation, Journal of Finance and Quantitative Analysis', Vol. 28, No. 3, pp. 347 - 362

Blair, M. M. and Schary, M. A. (1993), 'Industry-Level Pressure to restructure', in Blair, M. M. (Ed.), The Deal Decade: What Takeovers and Leveraged Buyouts mean for Corporate Governance, The Brookings Institute, Washington, D.C.

Borer, M. C. (1972), The British Hotel Through The Age, The Trinity Press, London

British Hospitality Association (1998 - 2004), 'Trends and statistics', British Hospitality Association, British Hospitality Association, London

Canina, L. (2001), Good News for buyers and sellers: Acquisitions in the Lodging Industry, Cornell Hotel \& Restaurant Administration Quarterly, December, Vol. 42, pp. 47 - 54

Cartwright, S. and Schoenberg, R. (2006), 'Thirty years of Mergers and Acquisitions Research: Recent advances and future opportunities', British Journal of Management, Vol. 17, Issue S1, March, pp. S1 - S5

Cassis, Y. (1997), Big Business, The European Experience in the Twentieth Century, Oxford University Press, Oxford

Channon, D. (1978), The Service Industries, Strategy, Structure \& financial Performance, MacMillan, London

Crawford-Welch, S. and Tse, E. (1990), Mergers, Acquisitions and Alliances in the European Hospitality Industry, International Journal of Contemporary Hospitality Management, Vol. 2, No. 1, pp. $10-16$

Dickson, M. (2002), Six Continents should keep its piggy bank - for now: A spat over hotel acquisition, The Financial Times (London edition), January 22, pp. 21

Caterer and Hotelkeeper (1986), 'Hotel property prices rocket - new report', Caterer and Hotelkeeper, 23 January, pp. 17 
Cosh, A. and Hughes, A. (2001), 'Managerial discretion and takeover performance', [Working Paper No. 216], ESRC Centre for Business Research, University of Cambridge

Dickson, M. (2002), 'Six Continents should keep its piggy bank - for now: A spat over hotel acquisition', The Financial Times (London edition), 22 January, pp. 21

Ennew, C. T., Wright, M. and Watkins, T. (1990), 'New Competition in financial Services', Long Range Planning, Vol. 23, No. 6, pp. 80 - 90

Feltham, C. (1987), Brewer buys Holiday Inns, The Times (London), September 16, pp. 21

Garcia, B. E. (1987), Stocks plunged in light trading on drop in bonds, Wobbly dollar, Wall Street Journal (Eastern Edition), September 16, pp. 1

Gaughan, P. A. (2007), Mergers, Acquisitions, and Corporate Restructurings, John, Wiley \& Sons, New York

Goergen, M. and Renneboog, L. (2004), Shareholder wealth effects of European Domestic and Cross-border Takeover Bids, European Financial Management, Vol. 10, No. 1, pp. 9-45

Goymour, D. (1987), 'Top 50 UK hotel group, Caterer and Hotelkeeper', 2 April, pp. 48 - 51

Goymour, D. (1988), 'Top 50 UK hotel group', Caterer and Hotelkeeper, 7 April, pp. 58 - 65

Goymour, D. (1989), 'Top 50 UK hotel group’, Caterer and Hotelkeeper, 27 April, pp. 60 - 66

Goymour, D. (1990), 'Room at the Top', Caterer and Hotelkeeper, 5 April, pp. 66 - 70

Goymour, D. (1991), 'Top of the Crop', Caterer and Hotelkeeper, 4 April, pp. 48 - 51

Goymour, D. (1993), 'Top 50, Caterer and Hotelkeeper’, 10 June, pp. 38 - 42

Goymour, D. (1994), 'The UK Top 50', Caterer and Hotelkeeper, 26 May, pp. 40 - 42 
Goymour, D. and Chitty, G. (1986), 'Top 50 UK hotel group', Caterer and Hotelkeeper, 13 March, pp. 40 - 42

Gugler, K., Mueller, D. C. and Yurtoglu, B. B. (2005), 'The determinants of merger waves', [Discussion Paper Series, 05 - 15], Tjalling C. Koopmans Research Institute, Utrecht School of Economics

Häkkinen, L., Norrman, A., Olli-Pekka, H. and Ojala, L. (2004), 'Logistics integration in horizontal mergers and acquisitions', International Journal of Logistics Management, Vol. 15, Issue 1, pp. $27-42$

Harford, J. (2005), 'What drives merger waves?' Journal of Financial Economics, September, Vol. 77, Issue 3, pp. $529-560$

Hitt, M., Harrison, J., Ireland, D. R. and Best, A. (1998), 'Attributes of Successful and Unsuccessful acquisitions of US firms, British Journal of Management', Vol. 9, pp. 91-114

Hopkins, H. D. (2008), 'International Acquisitions: Strategic considerations', International Research Journal of Finance and Economics, Issue 15, pp. 261 - 270

Hotels (1990), 'The top 200 Corporate chains, Hotel \& Restaurant International', July, Vol. 24, No. 7 , pp. $52-74$

Hotels (1991), 'Hotel 300: The world's largest companies', Hotel \& Restaurant International, July, Vol. 25, No. 7, pp. $40-99$

Hotels (1992), 'World's largest 200 corporate chains', Hotel \& Restaurant International, July, Vol. 26, No. 7, pp. $61-74$

Hotels (1993), 'World's Largest 200 Corporate chains', Hotel \& Restaurant International, July, Vol. 27, No. 7, pp. $44-58$

Hotels (1994), 'Hotels 200 Corporate chains', Hotel \& Restaurant International, July, Vol. 28, No. 7 , pp. $48-54$ 
Hotels (1995), 'Hotels 200 Corporate chains', Hotel \& Restaurant International, July, Vol. 29, No. 7 , pp. $38-44$

Hotels (1996), 'Hotels 200 Corporate chains', Hotel \& Restaurant International, July, Vol. 30, No. 7 , pp. $46-52$

Hotels (1997), 'Hotels 200 Corporate chains', Hotel \& Restaurant International, July, Vol. 31, No. 7, pp. $48-54$

Hotels (1998), 'Hotel's Corporate 300', Hotel \& Restaurant International, Vol. 32, July, No. 7, pp. $56-66$

Hotels (1999), 'Hotel's Corporate 300 ranking', Hotel \& Restaurant International, July, Vol. 33, No. 7 , pp. $50-60$

Hotels (2000), 'Hotel's Corporate 300 ranking', Hotel \& Restaurant International, July, Vol. 34, No. 7 , pp. $50-60$

Hotels (2001), 'Hotel's Corporate 300 ranking', Hotel \& Restaurant International, July, Vol. 35, No. 7 , pp. $52-62$

Hotels (2002), 'Hotel's Corporate 300 ranking', Hotel \& Restaurant International, July, Vol. 36 , No. 7 , pp. $46-56$

Hotels (2003), 'Hotel's Corporate 300 ranking', Hotel \& Restaurant International, July, Vol. 37, No. 7 , pp. $40-50$

Hotels (2004), 'Hotel's Corporate 300 ranking', Hotel \& Restaurant International, July, Vol. 38 , No. 7 , pp. $40-51$

Hotels (2005), 'Hotel's Corporate 300 ranking', Hotel \& Restaurant International, July, Vol. 39, No. 7 , pp. $35-46$

Hotel \& Restaurant International (1984), 'World's 200 Largest Hotel Chains', Hotel \& Restaurant International, August, Vol. 18, No. 6, pp. $52-83$ 
Hotel \& Restaurant International (1985), 'World's 200 Largest Hotel Chains', Hotel \& Restaurant International, July / August, Vol. 19, No. 7, pp. $47-87$

Hotel \& Restaurant International (1986), 'World's 200 Largest Hotel Chains', Hotel \& Restaurant International, July, Vol. 20, No. 7, pp. 48 - 86

Hotel \& Restaurant International (1987), '200 Leading Hotel Chains in 40 countries report 2.7 million rooms', Hotel \& Restaurant International, July, Vol. 21, No. 7, pp. $42-82$

Hotel \& Restaurant International (1988), 'World's 200 Largest Hotel Chains near 3 million rooms', Hotel \& Restaurant International, July, Vol. 22, No. 7, pp. $48-86$

Hotel \& Restaurant International (1989), '200 Corporate chains operate 2.8 million rooms', Hotel \& Restaurant International, July, Vol. 23, No. 7, pp. $46-84$

House of Commons (2004), 'Pub companies, Second Report of Session 2004 - 05', House of Commons Trade and industry Committee, published on December 21, 2004, London: The Stationary Office Limited

Jensen, M. C. (1986), 'Agency cost of Free Cash Flow, Corporate Finance and Takeovers', American economic Review, Vol. 76, No. 2, pp. 323-329

Jensen, M.C. and Meckling, W. H. (1976), 'Theory of the firm: Managerial behaviour, agency costs and ownership structure', Journal of Financial Economics, Vol. 3, pp. 305-360

Jeremy, D. J. (1998), A Business History of Britain 1900-1990s, Oxford University Press, Oxford

Kim, K. and Olsen, M. (2008), 'Determinants of successful acquisition processes in the US lodging industry', International Journal of Hospitality Management, Vol. 18, No. 3, pp. 285 - 308

Kiymaz, H. and Baker, H. K. (2008), 'Short-term performance, industry effects and motives: Evidence from large M\&As', Quarterly Journal of Finance and Accounting, Vol. 47, No. 2, pp. 17 $-31$ 
Klasa, S. and Stegemoller, M. (2007), 'Takeover Activity as a Response to Time-Varying Changes in Investment Opportunity Sets: Evidence from Takeover Sequences Financial Management', Financial Management, Summer, Vol. 36, No. 2, pp. 19 - 43

Kwansa, F.A. (1994), Acquisitions, Shareholder Wealth and the Lodging sector: 1980-1990, International Journal of Contemporary Hospitality Management, Vol. 6, No. 6, pp. $16-22$

Lubatkin, M. (1983), 'Mergers and the performance of the acquiring firm', Academy of Management Review, Vol. 8, No. 2, pp. 218 - 225

Mahajan, V., Rao, V. R. and Srivastava, R. K. (1994), 'An approach to assess the importance of brand equity in acquisition decisions', Journal of Product Innovation Management, Vol. 11. Pp. 221-235

Mahoney, J. and Rueschemeyer, D. (2003), Comparative Historical Analysis, in Mahoney, J. and Rueschemeyer, D. (Eds.), Comparative Historical analysis in the social science, Cambridge University Press, Cambridge, pp. 3 - 38

Marris, R. (1964), The Economic theory of "Managerial" Capitalism, Free Press, New York

Medlik, S. and Airey, D. W. (1978), Profile of the Hotel and Catering Industry, William Heinmann Ltd, London

Mintel (2005), Remote Betting, August, Mintel International Group Limited, London

Mintel (2006), Casino, November, Mintel International Group Limited, London

Mitchell, M. L. and Mulherin, J. H. (1996), 'The impact of Industry Shocks on Takeover and Restructuring Activity', Journal of Financial Economics, Vol. 41, pp. 193 - 229

Mukherjee, T. K., Kiymaz, H. and Baker, H. K. (2004), 'Merger Motives and Target Valuation: A Survey of Evidence from CFOs', Journal of Applied Finance, Fall / Winter, Vol. 14, Issue 2, pp. $7-24$

Mulherin, J. H. and Boone, A. L. (2000), 'Comparing acquisitions and divestitures', Journal of Corporate Finance, Vol. 6, pp. $117-139$ 
Nickson, D. (1997), @Colourful Stories@ or historical insight? - A review of the Auto/Biography of Charles Forte, Conrad Hilton, J.W. Marriott and Kemmons Wilson, Journal of Hospitality \& Tourism Research, Vol. 21, No. 1, pp. 179-192

Office for National Statistics (2000). 'Travel Trends, A Report on the 1999 International Passenger Survey', available at:

http://www.statistics.gov.uk/downloads/theme transport/Ttrends1999.pdf, (accessed 15 September 2009).

Office for National Statistics (2009). 'MQ6 Tranport Travel and Tourism, Overseas Travel and Tourism Quarter 1 2009', available at:

http://www.statistics.gov.uk/downloads/theme transport/mq6-q1-2009.pdf, (accessed 15 September 2009).

Pope, R. (2000), A consumer Service in Interwar Britain: The Hotel Trade, 1924-1938, Business History Review, Winter, Vol 74, No 4, pp. 657 - 682

Pope, R. (2001), Railway Companies and Resort Hotels between the War, Journal of Transport History, Vol. 22, No. 1), pp. 62 - 73

Punch, K. F. (2000), Developing effective research proposals, SAGA, London

Reid, M. (1988), All-changes in the City, The Revolution in Britain's Financial Sector, The MacMillan Press, London

Salter, M. S. and Weinhold, W. A. (1978), 'Diversification via acquisition: creating value, Harvard Business Review', July-August, pp. 166-176

Saunders, M. N. K., Lewis, P. and Thornhill, A. (2007), Research methods for business students, Financial Times Prentice Hall, Harlow

Schoenberg, R. (2003), 'Mergers and Acquisitions, Motives, Value creation, and implementations', in Faulkner, D. O. and Campbell, A. (Eds.) The Oxford Handbook of Strategy Vol. II: Corporate Strategy, Oxford University Press, Oxford, pp. 95 - 117

Scott, P. (1996), The property masters: a history of the British commercial property sector, E \& FN Spon, London 
Simmons, J. (1984), Railways, hotels and tourism in Great Britain 1839 - 1914, Journal of Contemporary History, April, Vol. 19, No. 2, pp. $201-222$

Singh, H. and Montgomery, H. (1987), 'Corporate Acquisition Strategies and Economic Performance', Strategic Management Journal, Vol. 8, pp. 377-386

Stewart, D. A. (1991), Business Profile: The growth and development of Trusthouse Forte, Tourism Management, December, pp. 341-351

Stewart, D. (1996), Hoteliers and Hotels: Case studies in the growth and development of UK hotel companies 1945-1989, Unpublished PhD Theses, Glasgow: Search Publications \& Consultancy Services

Taylor, D. (2003), Ritzy: British Hotels 1837-1987, The Milman Press, London

Taylor, D. and Bush, D. (1974), The Golden Age of British Hotels, Northwood, London

Teece, D. J. (1980), 'Economies of scope and the Scope of an enterprise', Journal of Behaviour Organization, September, Vol. 1, Issue 3, pp. 233 - 247

Toxvaerd, F. (2004), 'Strategic merger waves: a theory of musical chairs', Journal of Economic Literature, May, pp. 1 - 29

Wardley, P. (1991), The Anatomy of Big Business: Aspects of Corporate Development in the Twentieth Century, Business History, April, Vol. 33, No. 2, pp. 268-296

Yin, R. K. (2009), Case Study Research: Design and Methods, SAGE Ltd., London 